\title{
Pandemia, desinformação e discurso autoritário: os sentidos das declarações de Jair Bolsonaro no Twitter a partir de checagens do Aos Fatos
}

\author{
Pandemic, disinformation and authoritarian speech: meanings of \\ Jair Bolsonaro's statements on Twitter checked by Aos Fatos \\ Taís Seibt ${ }^{a, *}$ \\ Murilo Dannenberg b
}

\begin{abstract}
RESUMO: O artigo identifica como características do comportamento autoritário sistematizadas por Levitsky e Ziblatt (2018) se revelam em declarações do presidente do Brasil, Jair Bolsonaro, verificadas pelo site de fact-checking Aos Fatos. A partir de uma análise de conteúdo, seguida de análise de sentidos das declarações de Bolsonaro no Twitter sobre a pandemia de Covid-19, o estudo permite tensionar autoritarismo e desinformação no discurso do presidente em meio à crise sanitária, bem como os desafios que isso representa para o fact-checking, o exercício do jornalismo e a democracia no contexto brasileiro. Palavras-chave: Autoritarismo; Desinformação; Fact-checking; Pandemia; Jornalismo.
\end{abstract}

ABSTRACT: The article identifies how the characteristics of authoritarian behavior systematized by Levitsky and Ziblatt (2018) are revealed in statements by the President of Brazil, Jair Bolsonaro, verified by the fact-checking website Aos Fatos. From a content analysis, followed by analysis of meanings of Bolsonaro statements on Twitter about the pandemic Covid-19, the study allows us to measure the authoritarianism and misinformation in the president's speech amid health crisis, and the challenges that represents for fact-checking, the exercise of journalism and democracy in the Brazilian context.

Keywords: Authoritarianism; Misinformation; Fact-checking; Pandemic; Journalism.

\footnotetext{
a Escola da Indústria Criativa, Universidade do Vale do Rio dos Sinos, São Leopoldo, RS, Brasil.

b Jornalista, Brasil.

*Correspondência para/Correspondence to: Taís Seibt. E-mail: tseibt@unisinos.br.
}

Recebido em/Received: 07/04/2021; Aprovado em/Approved: 16/06/2021.

Artigo publicado em acesso aberto sob licença CC BY 4.0 Internacional $($ )(i) 


\section{INTRODUÇÃO}

Nos últimos anos, tem se observado uma escalada do discurso autoritário entre líderes políticos mundo afora, de Viktor Orbán (Hungría) a Donald Trump (EUA). Com largo histórico de defesa da Ditadura Militar e de falas contrárias aos Direitos Humanos em mais de duas décadas como parlamentar no Brasil, Jair Bolsonaro, eleito presidente em 2018, mostrou a face brasileira do fenômeno já na campanha eleitoral daquele ano. Em 2020, no segundo ano de mandato, alimentando-se da pandemia do novo coronavírus, o presidente engendrou-se em uma série de atos e declarações questionáveis em seus canais de comunicação durante a maior crise sanitária do século. Com discurso ora negacionista ora incitando ódio contra adversários políticos e outros poderes, Bolsonaro teve voz ativa na propagação de desinformação ${ }^{1}$ sobre a Covid-19 no Brasil, sendo alvo frequente de agências de fact-checking.

O site Aos Fatos, expoente brasileiro de fact-checking, mantém uma seção específica para verificar as declarações do presidente, atribuindo a elas etiquetas que adjetivam o discurso conforme o grau de veracidade. A partir de um recorte analítico desse banco de checagens, buscamos relacionar as declarações do presidente com indicadores de discurso autoritário (Levitsky; Ziblatt, 2018), a fim de tensionar os impactos desse comportamento no jogo democrático - e no exercício jornalístico - no contexto brasileiro.

O fact-checking vem ganhando destaque no Brasil desde 2014, mas foi especialmente consolidado a partir de 2018, durante a campanha presidencial. Apesar da sua contribuição para a elucidação da veracidade de declarações, o fact-checking nem sempre dá conta de elementos discursivos, que não são checáveis por sua metodologia. Baseando-se no factual e no que é passível de verificação com base em evidências, esses conteúdos respondem apenas em parte aos desafios da desinformação, pois a baixa qualidade de certas declarações nem sempre diz respeito a estatísticas equivocadas ou dados imprecisos. Tendências autoritárias e ataques a instituições, incluindo a imprensa, também são nocivos à democracia.

Neste estudo ${ }^{2}$, buscamos identificar com que frequência as falas de Jair Bolsonaro no Twitter, canal que desde o início do governo é um dos principais meios de pronunciamento do presidente, evocam discursos antidemocráticos e como eles se relacionam com as classificações de veracidade atribuídas pelo fact-checking. Ao estabelecer nexos entre o selo aplicado pelo site Aos Fatos e os sentidos de discurso

\footnotetext{
${ }^{1}$ Um levantamento do Radar Aos Fatos, mecanismo automatizado que monitora conteúdos de baixa qualidade nas plataformas digitais, mostrou que Bolsonaro e aliados foram responsáveis por $83 \%$ das publicações mais populares no Facebook sobre "tratamento precoce" de Covid-19, baseado na defesa de medicamentos sem comprovação científica. (BARBOSA et.al., 2021)

${ }^{2}$ Este artigo apresenta resultados parciais da pesquisa "Epidemia do autoritarismo: A crise sanitária e o discurso autoritário do presidente do Brasil no Twitter", apresentada como requisito para conclusão da graduação em Jornalismo na Unisinos em 2020, de autoria de Murilo Dannenberg, sob orientação de Taís Seibt.
} 
autoritário presentes nos conteúdos verificados, podemos tensionar a relação entre desinformação e autoritarismo.

Tomamos como parâmetro de análise os quatro principais indicadores de comportamento autoritário tabulados por Steven Levitsky e Daniel Ziblatt, no livro "Como as democracias morrem?", lançado em 2018 no Brasil. Apesar do foco principal da obra ser as eleições estadunidenses presidenciais de 2016, que culminaram na vitória de Donald Trump, o livro apresenta-se como um manual para identificar elementos comuns à deterioração da democracia em qualquer parte do mundo, através de pontos recorrentes no levante de diversos autocratas e demagogos. A opção por essa referência se deve ao seu recente lançamento, sendo contemporânea de outros estudos sobre a escalada de desinformação na comunicação. Sua construção, baseada em uma análise macro do comportamento autoritário de diferentes políticos e épocas, aliada à sistematização de indicativos do discurso autoritário (Quadro 2), permite sua replicabilidade com o comportamento de outros expoentes políticos.

O recorte analítico inclui as publicações do presidente no Twitter de 24 de março até $1^{\circ}$ de junho, verificadas pelo site Aos Fatos ${ }^{3}$. A escolha pelo período da pandemia de Covid19 está ligada diretamente ao que Levitsky e Ziblatt (2018), entre outros autores, apontam como um dos cenários em que o autoritarismo se desenvolve: uma crise. Utilizamos uma base de dados fornecida pelo Aos Fatos com 81 declarações do presidente envolvendo o tema da Covid-19 no período de recorte. Optou-se pela base de tuítes verificados pelo Aos Fatos ao invés da coleta direta de postagens do presidente, pois o estudo pretende analisar as relações entre o selo atribuído pelo factchecking quanto à precisão dos dados citados pelo presidente e as características de discurso autoritário ou antidemocrático, de forma a problematizar a associação entre desinformação e autoritarismo.

A análise do corpus mesclou técnicas de análise de conteúdo e de análise de sentidos, a fim de identificar as declarações mais repetidas por Bolsonaro, qual o selo de checagem atribuído a elas, a data e a frequência dessas declarações, sua evolução ao longo do período de recorte e, principalmente, a presença do autoritarismo nas publicações bolsonaristas e sua implicação no processo de desinformação. Os resultados são apresentados em caráter descritivo, tendo em vista as limitações inerentes ao espaço de um artigo científico, trazendo exemplos que permitem destacar como se manifestam as características do discurso autoritário e suas relações com os selos de veracidade atribuídos pelo Aos Fatos para tensionar as limitações do

\footnotetext{
${ }^{3}$ O Aos Fatos foi fundado em 2015 com o objetivo de acompanhar "declarações de políticos e autoridades de expressão nacional, de diversas colorações partidárias, de modo a verificar se eles estão falando a verdade". Para isso, o site seleciona informações públicas "a partir de sua relevância - seja porque uma autoridade pública a endossou, seja porque tem alto engajamento nas redes sociais" e procura "por fontes de origem confiável para conferir se a mensagem confere" (AOS FATOS, s/d, online).
} 
fact-checking e os desafios ao exercício do jornalismo no Brasil em um contexto de acirramento do autoritarismo em meio à crise sanitária.

\section{Bolsonaro no Twitter}

A relação entre desinformação e ascensão de líderes autoritários e populistas ao poder nos últimos anos vem sendo problematizada por diversos autores e há preocupação com as implicações a longo prazo dessas campanhas "concebidas especificamente para semear a desconfiança e aguçar a divisão dos interesses socioculturais existentes por meio da criação de tensões nacionalistas, étnicas, raciais e religiosas" (Wardle e Derakshshan, 2017, p. 4). Para Da Empoli (2020, p. 88), é parte da estratégia discursiva dos "engenheiros do caos" explorar "a indignação, o medo, o preconceito, o insulto, a polêmica racista ou de gênero" para conquistar eleitores, pois sabem que esses "proporcionam muito mais atenção e engajamento que os debates enfadonhos da velha política”.

Conforme Prior (2019, p. 124), a crise das democracias representativas favorece o "discurso simplista sobre a realidade social, baseando-se na vontade popular para alcançar o poder e para combater um inimigo do povo, geralmente identificado com a elite". Essa estratégia discursiva se vale da polarização, o "nós contra eles", estimulando o conflito e a instabilidade democrática. Conforme Viscardi (2020, p. 1153): "Nós poderia ser entendido como os homens comuns ("homens de bem" no contexto brasileiro?); eles seria entendido tanto como os estrangeiros quanto os indivíduos que pensam e/ou se comportam de maneira diferente do estabelecido/previsto por aquele grupo político".

Para Viscardi (2020), o uso político de canais em redes sociais cria pontes diretas entre as personalidades e o público, sem o papel intermediário do jornalismo. No caso específico de Bolsonaro, analisado pela autora, o canal potencializa a divulgação de suas definições particulares de "verdade" e "mentira". Segundo Viscardi, é comum que atores políticos utilizem as redes para construção de suas próprias personas e disseminação de seus interesses. Junto com isso, há uma divulgação desenfreada de "ideias de todo tipo (incluindo teorias conspiratórias e informações falsas e manipuladas) e a captação de eleitores" (Viscardi, 2020, p. 1137).

Em síntese, o comportamento do presidente brasileiro no Twitter se qualifica pelo uso de uma linguagem direta, observando algumas características do "internetês" - assim chamado o dialeto da internet - como usar caixa alta para enfatizar o próprio discurso, estimulando uma interpretação de que Bolsonaro está gritando algo que seu público precisa saber, o que também cria proximidade afetiva. Viscardi aponta que Bolsonaro constrói a persona de um "homem simples", com o intuito de se aproximar de seu público. Com isso, ele consegue, por exemplo, mobilizar ódio em seus interlocutores, mirando, além de adversários políticos, a imprensa. Ele cria conexões com seus seguidores, utilizando temas de recorrente insatisfação popular, como o discurso anticorrupção, e a alegação de ser perseguido por uma suposta parcialidade dos jornalistas. Desse modo, aproveita-se das redes sociais para divulgar sua própria 
narrativa, coloca-se como figura central que dita a realidade a ser replicada por seus seguidores.

[...] o populismo raivoso de Bolsonaro ganha força na exploração de um cenário de crise, em que os discursos de ódio ao Partido dos Trabalhadores (do candidato Fernando Haddad) e de combate à corrupção refletem a insatisfação de uma parte da população com os políticos brasileiros e os aproxima. Na mobilização desses afetos, Bolsonaro cria e fortalece a identificação com esse povo que, embora possa ter inúmeras diferenças, «se encontra» na equivalência da insatisfação crescente. Assim, a raiva de Jair Bolsonaro é uma marca que define e molda não só a sua mensagem, que se vê corporificada na persona do atual presidente, mas também define o próprio populismo, que se vale dessa dimensão para criar um sentido de união de um grupo e estabelecer a identificação desse grupo com seu líder. (VISCARDI, 2020, p. 1153)

Nessa disputa discursiva, a verdade factual perseguida pelos fact-checkers é posta em xeque, pois a narrativa impetrada pelo líder influenciador, com forte apelo emocional, fala mais alto do que as evidências. É um retrato típico do ambiente de "pós-verdade", em que "fatos objetivos têm menos influência em moldar a opinião pública do que apelos à emoção e a crenças pessoais"4, conforme definiu o Dicionário Oxford em 2016. A esse conceito, adiciona-se outro neologismo criado em 2020, a noção de "infodemia". Segundo a Organização Mundial da Saúde (OMS), a partir de Zarocostas (2020), trata-se de: "Um excesso de informações, algumas precisas e outras não, que tornam difícil encontrar fontes idôneas e orientações confiáveis quando se precisa" (Organização Panamericana de Saúde, 2020, p. 2). Com velocidade de propagação comparável à de um vírus, a infodemia poderia potencializar a pandemia.

Pós-verdade e infodemia são conceitos que se aproximam da "desordem informacional" ou do fenômeno da "desinformação". Desinformação é o termo proposto por Wardle e Derahkshan (2017) como substitutivo a "fake news", expressão questionada no meio acadêmico. Segundo Ribeiro e Ortellado (2018, p. 72), há os que defendem o uso de "fake news" como conceito forjado no debate político e na cobertura jornalística e os que o consideram impreciso, especialmente por contradizer os princípios deontológicos do jornalismo que colocam a busca pela verdade factual como algo intrínseco ao conceito de notícia, de modo que não se pode conceber a noção de "notícia falsa", pois como observa Gomes (2009, p.11), o jornalista deve "trabalhar objetiva e metodicamente para afastar o risco do engano ou do erro".

Ao abordar a desordem informacional sob a perspectiva da desinformação, Wardle e Derakhshan (2017) a subdividem em três tipos: misinformation, que seria a mensagem enganosa compartilhada sem o intuito de causar dano; malinformation, a mensagem que pode até ser verdadeira, mas em geral é de foro íntimo ou pode causar constrangimento e escândalo se vier a público, e é compartilhada com o intuito de

\footnotetext{
${ }^{4}$ Relating to or denoting circumstances in which objective facts are less influential in shaping public opinion than appeals to emotion and personal belief. In: https://en.oxforddictionaries.com/definition/post-truth
} 
prejudicar um oponente político, por exemplo; e disinformation, o conteúdo fabricado, fake, produzido e compartilhado com o objetivo de causar dano. No contexto da infodemia, onde não se diferencia o que se pode ou não confiar, estão presentes tanto aspectos de misinformation quanto disinformation, sendo que ambos podem ser impactados pela polarização política, que se refletiu também no debate público sobre a crise sanitária da Covid-19.

Tendo a infodemia como pano de fundo, a análise das declarações de Bolsonaro no Twitter ganha relevo não só pela identificação de sintomas de autoritarismo no discurso do presidente, mas também pelas consequências de suas falas no processo de desinformação durante a pandemia de Covid-19 e ainda na correlação entre esses dois aspectos.

O corpus que serviu de base para as análises corresponde aos primeiros meses da pandemia no Brasil. Selecionamos apenas as publicações que receberam alguma classificação temática relacionada ao novo coronavírus, conforme os critérios do site Aos Fatos ${ }^{5}$. No entanto, como ainda encontramos uma quantidade elevada - 81 tuítes - para fazermos uma análise acurada, aplicamos a análise de conteúdo, conforme Bardin (2000), para recategorizar os posts bolsonaristas mais relevantes para os nossos objetivos. Todas as declarações presidenciais são compiladas pelo Aos Fatos, com as respectivas conclusões da checagem, em um arquivo de formato CSV (commaseparated values), que é de fácil visualização em qualquer agregador de planilhas. Com o objetivo de correlacionar as etiquetas do Aos Fatos com as categorias criadas para a análise de conteúdo, incluímos no arquivo agregado de publicações presidenciais a nova coluna "Categoria", conforme o Quadro 1.

Quadro 1. Categorias criadas para análise do discurso de Jair Bolsonaro

\begin{tabular}{|l|l|}
\hline Agenda/Divulgação & $\begin{array}{l}\text { Inclui todas as publicações de Bolsonaro que versam sobre dados } \\
\text { oficiais do governo, divulgações de datas de ações federais, bem } \\
\text { como informações com dados públicos já comprovados. }\end{array}$ \\
\hline Cloroquina & $\begin{array}{l}\text { A categorização específica sobre a cloroquina se deve ao grande } \\
\text { número de declarações do presidente sobre o tema. Também } \\
\text { optamos por fazer essa segmentação pelas características } \\
\text { peculiares que envolvem o assunto. A escolha do medicamento } \\
\text { como elemento central em combate ao vírus colocou o discurso } \\
\text { do líder do país contra recomendações da OMS, da cobertura da } \\
\text { imprensa e das pesquisas, que não validam evidências de } \\
\text { benefícios da cloroquina no tratamento da Covid-19. }\end{array}$ \\
\hline
\end{tabular}

5 A tabela fornecida pelo site continha uma classificação própria quanto ao assunto da declaração, sendo utilizadas de forma individual ou agrupadas, por exemplo Coronavírus/Imprensa; Coronavírus/Justiça; Coronavírus/Economia. Foram mantidas no corpus tanto as classificadas apenas como "coronavírus" quanto as categorizadas como "coronavírus" e outras categorias. 


\begin{tabular}{|l|l|}
\hline Contexto internacional & $\begin{array}{l}\text { Nos primeiros meses de pandemia no Brasil, Bolsonaro utilizava a } \\
\text { comparação com casos de outros países para minimizar a } \\
\text { situação no Brasil. }\end{array}$ \\
\hline Economia & $\begin{array}{l}\text { Agrupa as declarações do presidente que majoritariamente falam } \\
\text { sobre ações de cunho econômico. Ainda que seja possível } \\
\text { encontrar especificações entre algumas publicações desta } \\
\text { categoria, o agrupamento une os tuítes que falam sobre ações do } \\
\text { governo na liberação de crédito, renegociação de dívidas, } \\
\text { mudanças em tarifas e auxílio-emergencial }\end{array}$ \\
\hline Imprensa & $\begin{array}{l}\text { Reúne as declarações do presidente que têm como principal } \\
\text { objetivo atacar ou desqualificar as ações ou a cobertura da } \\
\text { imprensa sobre a Covid-19 e o posicionamento do governo. }\end{array}$ \\
\hline Outros poderes & $\begin{array}{l}\text { Publicações sobre outros poderes (Judiciário, Legislativo e outras } \\
\text { esferas do Executivo). }\end{array}$ \\
\hline Política de Saúde & $\begin{array}{l}\text { Declarações que falam sobre o posicionamento do governo no no da saúde. } \\
\text { combate ao coronavírus, dentro da área da } \\
\text { Diferentemente da categoria de Agenda/Divulgação, aqui as } \\
\text { publicações não têm relação direta com dados reais ou ainda } \\
\text { trazem dados sem comprovação. }\end{array}$ \\
\hline
\end{tabular}

Fonte: Dannenberg, 2020, pp.45-46.

Bardin (2000) já defendia que a categorização é parte central para simplificar o processo de análise. Para isso, atentamos às qualidades desenvolvidas pela autora. Colocamos apenas uma categoria por tuíte, atendendo ao princípio de "exclusão mútua”, que define que cada item pode receber apenas uma categoria. Também evitamos criar categorias que fossem aplicáveis a mais de uma publicação, conforme a "homogeneidade" definida por Bardin (2000).

As categorias foram também desenvolvidas observando as nuances do corpus. Em um contexto de pandemia e sendo Bolsonaro presidente de uma das principais economias emergentes do mundo, as categorias visam agrupar os itens de acordo com o meio político, em agrupamentos como agenda, políticas públicas, economia, dentre outros. Com isso, visamos atender à "pertinência" definida por Bardin (2000).

\section{Síntese dos dados}

Para resumir os dados da planilha, criamos tabelas sintetizadas com informações das principais colunas da base de dados. A primeira delas agrupa os totais da coluna "Selo", que é o resultado final do trabalho de checagem, com a atribuição de veracidade da declaração. Das 81 publicações de Jair Bolsonaro no período analisado, apenas 53 $(65,43 \%)$ são verdadeiras. Isso significa que mais de um terço - $28(34,56 \%)$ - das 
publicações presidenciais no Twitter apresentam algum tipo de dificuldade de comprovação ou são deliberadamente falsas, conforme classificação do Aos Fatos.

Tabela 1. Análise percentual das etiquetas dadas aos tuítes presidenciais.

\begin{tabular}{lcc}
\hline Selo & $\mathbf{N}^{\circ}$ de publicações & \% sob o total (81) \\
Verdadeiro & 53 & $65,43 \%$ \\
Falso & 7 & $8,64 \%$ \\
Exagerado & 1 & $1,23 \%$ \\
Impreciso & 11 & $13,58 \%$ \\
Insustentável & 3 & $3,70 \%$ \\
Contraditório & 6 & $7,41 \%$ \\
\hline
\end{tabular}

Fonte: Dannenberg, 2020, p. 50 a partir dos dados do site Aos Fatos.

Contudo, é preciso analisar mais de perto os tuítes verdadeiros do presidente. Das 53 publicações, 46 ficaram dentro da categoria de Agenda/Divulgação. Isso significa que em $86,79 \%$ das vezes em que falou a verdade, Bolsonaro estava divulgando as ações das pastas do seu governo ou compartilhando dados já verificados. Sobraram apenas sete postagens, ou 13,21\% (em relação aos tuítes verdadeiros) que receberam a etiqueta de "Verdadeiro" pela checagem do Aos Fatos.

Tabela 2. Análise do peso de cada categoria no total de publicações do corpus

\begin{tabular}{|c|c|c|}
\hline Categoria & $\mathrm{N}^{\circ}$ de publicações & \% sob o total (81) \\
\hline Agenda & 49 & $60,49 \%$ \\
\hline Cloroquina & 6 & $7,41 \%$ \\
\hline $\begin{array}{l}\text { Comparação } \\
\text { Internacional }\end{array}$ & 5 & $6,17 \%$ \\
\hline Economia & 6 & $7,41 \%$ \\
\hline Imprensa & 2 & $2,47 \%$ \\
\hline Outros Poderes & 3 & $3,70 \%$ \\
\hline Política de Saúde & 10 & $12,35 \%$ \\
\hline
\end{tabular}

Fonte: Dannenberg, 2020, p.51 a partir dos dados do site Aos Fatos.

A categoria que mais apareceu no conjunto de publicações de Bolsonaro analisadas foi "Agenda/Divulgação", com 49 tuítes. Como explicitado antes, essas postagens, em grande parte, tratam de ações planejadas ou executadas pelo governo. Ainda que 
possam carregar especificidades no contexto de saúde ou econômico, no geral divulgam ações concretas de Bolsonaro, como no exemplo a seguir:

FIGURA 1. Reprodução de tuíte de Bolsonaro categorizado como "Agenda/Divulgação".

\section{1- $\mathrm{R} \$ 2$ bilhões liberados para hospitais filantrópicos;}

12 Mais de 300 mil kits de higiene com 1,5 milhão de produtos de limpeza e higiene, montados e distribuídos pela Forças Armadas; @DefesaGovBr

\section{3- atingidas 2,2 mil agências da @Caixa abertas aos} sábados;

Translate Tweet

\section{6:41 AM - May 31, 2020 - Twitter for iPhone}

Fonte: Reprodução do Twitter de Jair Bolsonaro.

Com esse entendimento, propomos uma nova filtragem à nossa base de dados. Por identificarmos que a categoria de "Agenda/Divulgação" - a com maior controle por parte do presidente - foi dominante entre as publicações verdadeiras de Bolsonaro, construímos uma nova tabela, removendo essas 49 publicações.

Tabela 3. Tuítes de Bolsonaro sem a categoria "Agenda/Divulgação"

\begin{tabular}{lcc}
\hline Selo & $\mathbf{N}^{\circ}$ de publicações & \% sob o total (35) \\
Verdadeiro & 7 & $20,00 \%$ \\
Falso & 7 & $20,00 \%$ \\
Exagerado & 1 & $2,86 \%$ \\
Impreciso & 11 & $31,43 \%$ \\
Insustentável & 3 & $8,57 \%$ \\
Contraditório & 6 & $17,14 \%$ \\
\hline
\end{tabular}

Fonte: Dannenberg, 2020, p.52 a partir dos dados do site Aos Fatos 
O cenário encontrado, ainda que devido às modificações no corpus original, indica empiricamente que Bolsonaro usa menos dados verdadeiros do que frases que se pode comprovar quando publica sobre assuntos sobre os quais não tem controle direto. Dentro dessa perspectiva, o presidente falou inverdades em $80 \%$ dos casos checados pelo Aos Fatos. O número de tuítes falsos e verdadeiros foi o mesmo no período: sete. As declarações imprecisas foram dominantes, com 11 casos. Em seis oportunidades, Bolsonaro publicou afirmações que contradisseram ou outras falas suas ou suas próprias ações. Além disso, em três vezes fez afirmações insustentáveis, especialmente ao tentar defender o uso da hidroxicloroquina como melhor tratamento à Covid-19, e em uma vez exagerou as ações do governo no combate ao coronavírus.

Dentro do contexto político-social vivido no período de amostragem, com instabilidade das instituições no Brasil e com cenário mundial de pandemia, duas constatações preliminares se apresentam: 1) Os selos indicadores são favoráveis a Bolsonaro, especialmente quando ele se manifesta sobre assuntos de agenda própria/governo ou quando fala sobre fatos e números consolidados, como quando utiliza internacionais de contágio; 2) Quando falou sobre outros assuntos, como políticas de saúde e outros poderes, Bolsonaro ficou, na maioria das vezes, mais distante de tuítes verdadeiros, pelos critérios de veracidade do Aos Fatos.

Cruzando as categorias desenvolvidas para análise de conteúdo com os selos de checagem do Aos Fatos, outros padrões comportamentais do presidente ficam evidentes. Na Tabela 4, verificamos que dentre as publicações que trazem informações verdadeiras, $86 \%$ se enquadram como Agenda. A célula mais destacada, na cor verdeescuro, mostra as publicações que já mencionamos e desconsideramos no recorte anterior. Fora dessa categoria, foram apenas seis tuítes verdadeiros sobre a pandemia. Destes, três falam sobre números já verificados em uma comparação com o cenário internacional. Os demais se enquadram como "Cloroquina"; "Economia" e "Política de Saúde".

Em razão do baixo número de "verdades" restantes, analisamos essas frases mais de perto. A publicação do presidente que se encaixa como "Cloroquina" e foi verificada como verdadeira pelo Aos Fatos fala, na verdade, sobre o protocolo médico da Prevent Sênior, empresa do ramo de planos de saúde. Essa publicação, apesar de verdadeira, não tem relação direta com as políticas públicas desenvolvidas pelo governo durante a pandemia. O tuíte presidencial que se encaixou na categoria de "Economia" e foi verificado como verdadeiro aborda a situação do emprego no país. 
Tabela 4. Cruzamento entre categorias criadas para a pesquisa e etiquetas do site Aos Fatos

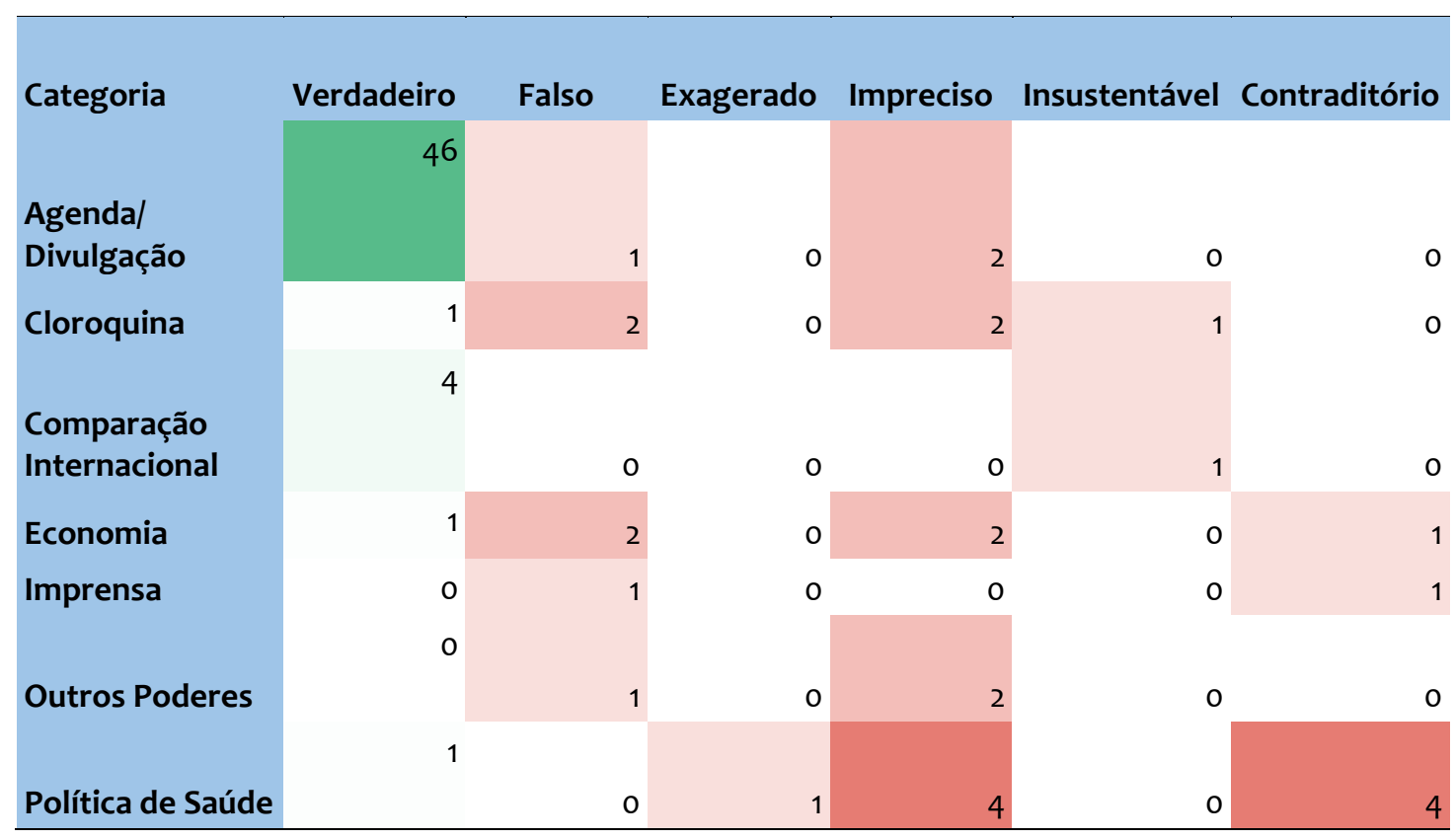

Fonte: Dannenberg, 2020, p.54 a partir dos dados do site Aos Fatos.

Figura 2. Bolsonaro tuíta informação descontextualizada sobre número de trabalhadores autônomos no Brasil

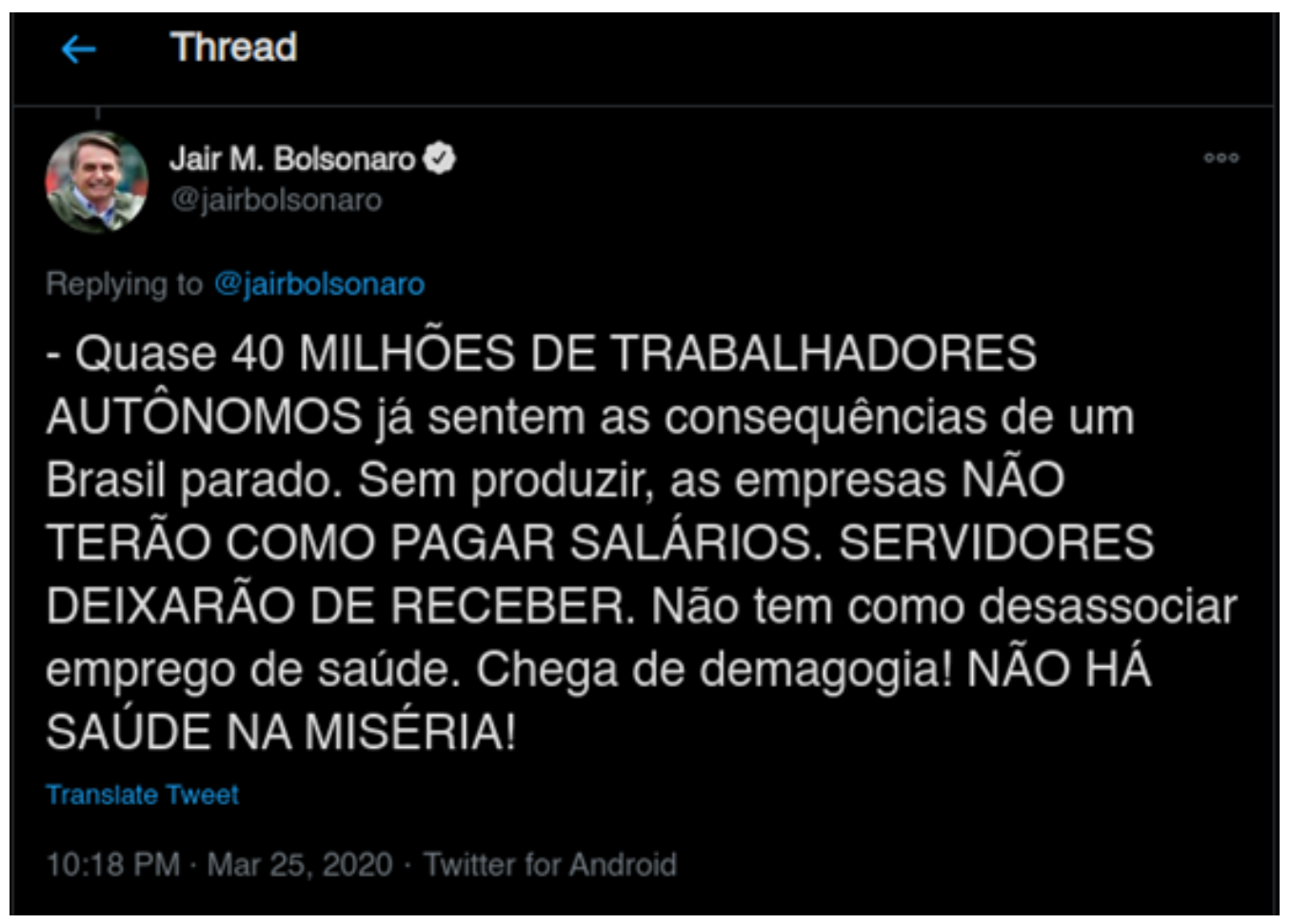

Fonte: Reprodução do Twitter de Jair Bolsonaro. 
Conforme observado pelo Aos Fatos, a fonte de informação que o presidente utilizou para fazer a publicação foi a PNAD Contínua (Pesquisa Nacional por Amostra de Domicílios Contínua), do Instituto Brasileiro de Geografia e Estatística (IBGE). Ainda que verdadeira, a publicação não reflete o contexto do emprego no Brasil à época. $O$ tuíte foi feito no dia 25 de março, um mês depois da divulgação da pesquisa. Em fevereiro, ainda não havia nenhuma política de restrição em curso no Brasil. Ao contrário, era celebrado o Carnaval no país. O cenário de desemprego que Bolsonaro aborda na sua fala é real, mas é anterior ao período de pico - e suas consequências de pandemia no país. O que permite ponderar que, embora os dados não sejam falsos, o discurso em que eles são citados carrega sentidos desconexos com a realidade.

Ao falar especificamente sobre cloroquina, Bolsonaro teve apenas uma frase etiquetada como verdadeira, que já trouxemos acima. Nas demais, o presidente fez publicações que não poderia sustentar com base em evidências. Por exemplo, Bolsonaro disse, no dia 8 de abril, que o uso da cloroquina se mostrava cada vez mais eficaz no tratamento contra a Covid-19. À época, estudos estavam sendo conduzidos, mas não havia ainda resultados confiáveis que justificassem a recomendação do tratamento. Em maio, a OMS fez o alerta de que o medicamento era comprovadamente ineficaz e, até o fechamento deste artigo, em março de 2021, os principais estudos e indicações da OMS não recomendam o uso da substância, pelo contrário, a contraindicam.

Quando fez uma série de tuítes, também chamada de thread, comparando os casos de pessoas infectadas com Covid-19 no Brasil com os números de outros países, Bolsonaro trouxe dados reais de todos os países, divulgados oficialmente. Ainda que os números fossem comprovados, o contexto situacional era divergente. Os países citados por Bolsonaro - Itália, França, Bélgica e Alemanha - estavam há mais tempo convivendo com o vírus. A thread foi publicada no dia 15 de abril, muito antes de o Brasil atingir o primeiro pico na curva de contágio e assumir a segunda colocação global nos números de casos e de mortos.

Como observado por Viscardi (2020), Bolsonaro costuma utilizar as redes para publicar suas próprias definições de verdade, o que fica claro nas suas publicações que falam sobre a imprensa. Com histórico de agressões a jornalistas e ao jornalismo como instituição, Bolsonaro apenas usou informações falsas ou se contradisse quando falou sobre a categoria. No dia 9 de abril, fez uma publicação comunicando que, ao sair de um dos hospitais das Forças Armadas, parou em uma farmácia para comprar medicamentos e acusou os repórteres de causarem aglomeração ao seu redor. Abril foi um dos meses em que Bolsonaro participou de aglomerações causadas por movimentos em seu apoio em frente ao Palácio do Planalto, em Brasília.

Outra categoria na qual Bolsonaro não passou dados verdadeiros nenhuma vez foi a de "Outros Poderes". Levitsky e Ziblatt (2018) apontam que um dos indicadores do comportamento autoritário é a deslegitimação dos outros poderes. Bolsonaro descontextualiza a realidade ao falar que cabe a governadores e prefeitos 
determinarem as medidas de restrição. Usamos a própria explicação do Aos Fatos para mostrar como o presidente cria sua própria realidade no Twitter.

\begin{abstract}
Bolsonaro faz referência à decisão tomada pelo ministro do STF (Supremo Tribunal Federal) Alexandre de Moraes ao analisar ação movida pela $\mathrm{OAB}$ (Ordem dos Advogados do Brasil) no dia 8 de abril. De acordo com o ministro, não cabe ao Poder Executivo Federal derrubar decisões de governos estaduais e municipais sobre isolamento social, quarentena e restrições ao funcionamento do comércio e de serviços. Isso não significa, no entanto, que quaisquer medidas de isolamento ligadas ao enfrentamento da Covid-19 sejam apenas de responsabilidade de governadores e prefeitos, como afirma o presidente. Na decisão, o ministro ressalta, inclusive, que o momento exige a união dos poderes e a cooperação entre as diversas esferas. (AOS FATOS, 2020)
\end{abstract}

O presidente ignora que a decisão do STF, na verdade, garante apenas a soberania das decisões regionais para aplicar novas ou maiores medidas restritivas. Bolsonaro eximese da responsabilidade de propor medidas de saúde contra a Covid-19, o que se reflete também na última categoria, "Política de Saúde". Das nove publicações nesse tema, apenas uma foi verificada como verdadeira pelo Aos Fatos. Com anúncios de ações sem grandes detalhes, a única informação verificada como verdadeira partiu de uma ação do governo estadunidense, que doou respiradores para o Brasil.

\title{
Elementos do autoritarismo
}

Numa segunda etapa analítica, utilizamos técnicas de análise de sentidos, segundo a metodologia de Moura e Lopes (2016), no intuito justamente de encontrar o sentido além do que está dito ou escrito. Com esse enfoque, a construção de contextualização através do contraponto das publicações com fatos observados e noticiados foi fundamental. Desse modo, apontam Moura e Lopes, é possível alcançar a camada ideológica do discurso, bem como identificar as características da personalidade em foco, o que atende ao objetivo de identificar se elementos de autoritarismo estão presentes em declarações de Jair Bolsonaro no Twitter.

Nossa principal referência para definir os indicativos do comportamento autoritário é de Levitsky e Ziblatt (2018). Para apontar os indícios de que a democracia está sendo desestabilizada pelos atores políticos, os autores apontam quatro elementos que podem ser observados com recorrência entre diferentes déspotas que levaram tirania ou repressão a seus respectivos países.

Dentre os casos citados como exemplos de políticos autoritários, destacam-se os que assumem o papel de outsider político. Com discurso anti-sistema, ou anti establishment, tais demagogos se colocam como a solução para os problemas crônicos da política. Fujimori, no Peru, e Chávez, na Venezuela, são alguns dos citados como representantes desse grupo. Cabe destacar que a publicação vem em sequência à eleição de Donald Trump, nos Estados Unidos. O empresário multimilionário assumiu com propriedade o papel de outsider. Uma das críticas vai para o próprio Partido 
Republicano, enquanto ator da democracia estadunidense. Como tal, teria a responsabilidade de identificar ou frear figuras como Trump, segundo os autores.

O pleito dos EUA de 2016 inspirou a extrema-direita pelo mundo, com reflexo inclusive no Brasil, em 2018, quando Jair Bolsonaro foi eleito presidente. Antes de oficializar sua candidatura, disse, em 2017, que via Donald Trump como um exemplo para ele $^{6}$. Mesmo atuando como político há 29 anos, na campanha presidencial assumiu um discurso de outsider no establishment brasileiro7, que, por mais contraditório que seja devido à sua longa carreira parlamentar, esse discurso foi um dos responsáveis pela eleição de Bolsonaro em 2018.

Quadro 2. Elementos do autoritarismo, por Levitsky e Ziblatt.

\begin{tabular}{|c|l|}
\hline 1. & Rejeição das regras democráticas do jogo (ou compromisso débil com elas) \\
\hline 2. & Negação da legitimidade dos oponentes políticos \\
\hline 3. & Tolerância ou encorajamento à violência \\
\hline 4. & Propensão a restringir liberdade civis de oponentes, inclusive a mídia \\
\hline
\end{tabular}

Fonte: (Levitsky e Ziblatt, 2018, pp.33-34).

A partir dos achados da análise de conteúdo, sintetizados na seção anterior, reduzimos o corpus a 11 tuítes para análise de sentidos (Moura; Lopes, 2016). Conforme os autores, a mídia escolhida como fonte dos discursos, no caso, o Twitter, encaixa-se como um objeto empírico do tipo 1 - "Textos, mídias tradicionais e organizações". Como vimos, publicações que se encaixam na categoria "Agenda/Divulgação" e foram checadas como verdadeiras pelo Aos Fatos são, em suma, postagens que falam sobre temas próximos ao controle do presidente, como a sua própria agenda e de ações do governo brasileiro. Assim, essas declarações foram desconsideradas. Por sua proximidade com indicativos de Levitsky e Ziblatt (2018), selecionamos as categorias "Outros Poderes" e "Imprensa". Já para nos aproximarmos ainda mais do assunto coronavírus, selecionamos também "Cloroquina” como última categoria a ser analisada.

A escolha da categoria "Outros Poderes" está diretamente relacionada aos dois primeiros itens do Quadro 2, que versam sobre "rejeição das regras democráticas do jogo" e "negação da legitimidade dos oponentes políticos" (Levitsky, Ziblatt, 2018, p. 33). Já a categoria "Imprensa" foi selecionada pela proximidade com o quarto item, ligado à propensão a restringir oponentes, população ou, no caso, a mídia. "Cloroquina" foi selecionada por ter sido a aposta do presidente no combate ao coronavírus. Além de usar dados verdadeiros apenas uma vez ao falar sobre o assunto

6 “O Trump serve de exemplo para mim", diz Bolsonaro em visita aos EUA. Folha de São Paulo. Disponível em <https://www1.folha.uol.com.br/poder/2017/10/1925626-o-trump-servede-exemplo-para-mim-diz-bolsonaro-em-visita-aos-eua.shtml> Acesso em 11/10/2020.

7 Disponível em <https://brasil.elpais.com/brasil/2018/10/05/politica/1538754620_596859.html>. Acesso em 29/06/2020. 
no Twitter, Bolsonaro entrou em contradição narrativa após o composto químico não encontrar justificativa científica para seu uso.

Quadro 3. Seleção final dos tuítes presidenciais

\begin{tabular}{|c|c|c|}
\hline Data & Publicação de Jair Bolsonaro & Categoria \\
\hline $01 / 04 / 2020$ & $\begin{array}{l}\text { Não é um desentendimento entre o Presidente e } \\
\text { ALGUNS governadores e ALGUNS prefeitos... São } \\
\text { fatos e realidades que devem ser mostradas. Depois } \\
\text { da destruição não interessa mostrar culpados. }\end{array}$ & Outros poderes \\
\hline $01 / 04 / 2020$ & $\begin{array}{l}\text { - Não há mudança de tom quando se fala em salvar } \\
\text { vidas após alertar sobre histeria, como sugere } \\
\text { determinada emissora. }\end{array}$ & Imprensa \\
\hline $08 / 04 / 2020$ & $\begin{array}{l}\text { 1- Há } 40 \text { dias venho falando do uso da } \\
\text { Hidroxicloroquina no tratamento do COVID-19. }\end{array}$ & Cloroquina \\
\hline $08 / 04 / 2020$ & $\begin{array}{l}\text { 2- Cada vez mais o uso da Cloroquina se apresenta } \\
\text { como algo eficaz. }\end{array}$ & Cloroquina \\
\hline $09 / 04 / 2020$ & $\begin{array}{l}\text { - Retornando do Hospital das Forças Armadas parei } \\
\text { para comprar medicamento na Drogaria Rosário. - } \\
\text { Contrariando normas da Saúde os repórteres se } \\
\text { aglomeraram. }\end{array}$ & Imprensa \\
\hline $11 / 4 / 2020$ & $\begin{array}{l}\text { [- Mais pontos importantes de ações do Governo } \\
\text { Federal divulgados nesta semana:] Ministro do STF } \\
\text { determina que ações de restrições são de } \\
\text { competência de governadores e prefeitos. }\end{array}$ & Outros poderes \\
\hline $11 / 4 / 2020$ & $\begin{array}{l}\text { [- Mais pontos importantes de ações do Governo } \\
\text { Federal divulgados nesta semana:] Hidroxicloroquina } \\
\text { sendo usada no mundo todo e avanços acontecem. }\end{array}$ & Cloroquina \\
\hline $19 / 04 / 2020$ & $\begin{array}{l}\text { Segundo o CEO Fernando Parrillo, a Prevent Senior } \\
\text { reduziu de } 14 \text { para } 7 \text { dias o tempo de uso de } \\
\text { respiradores e divulgou hoje, às } 1 \text { h40 da manhã, o } \\
\text { complemento de um levantamento clínico feito. }\end{array}$ & Cloroquina \\
\hline $19 / 04 / 2020$ & $\begin{array}{l}\text { De um grupo de } 636 \text { pacientes acompanhados pelos } \\
\text { médicos, } 224 \text { NÃO fizeram uso da hidroxicloroquina. } \\
\text { Destes, } 12 \text { foram hospitalizados e } 5 \text { faleceram. }\end{array}$ & Cloroquina \\
\hline $23 / 4 / 2020$ & $\begin{array}{l}\text { O Conselho Federal de Medicina autorizou a } \\
\text { utilização de cloroquina e hidroxicloroquina em } \\
\text { pacientes com sintomas leves a partir da } \\
\text { confirmação do diagnóstico de Covid-19. }\end{array}$ & Cloroquina \\
\hline $31 / 05 / 2020$ & $\begin{array}{l}\text { [MAIS AÇÕES DO GOVERNO DO BRASIL } \\
\text { desenvolvidas na terceira semana de maio. (Parte 3)] } \\
\text { B. Apesar da responsabilidade diante do trabalhador } \\
\text { na pandemia ser dos estados e municípios, o @govbr } \\
\text { desenvolve programa preservando até então mais de } \\
\text { 8,1 milhões de empregos no país; }\end{array}$ & Outros poderes \\
\hline
\end{tabular}

Fonte: Dannenberg, 2020, p. 90. 
Na categoria "Outros Poderes", a primeira publicação analisada já mostrou que Bolsonaro compartilhou uma publicação classificada pelo Aos Fatos como falsa para atacar politicamente governadores e prefeitos que estavam contrariando seu discurso negacionista. Enquanto se recusava a adotar políticas de isolamento social e de combate ao novo coronavírus, o presidente publicou um vídeo em que um homem afirma já estar ocorrendo desabastecimento em um centro de distribuição de itens básicos de Minas Gerais.

Figura 3. Bolsonaro compartilha vídeo com informação falsa sobre a Ceasa de Minas Gerais

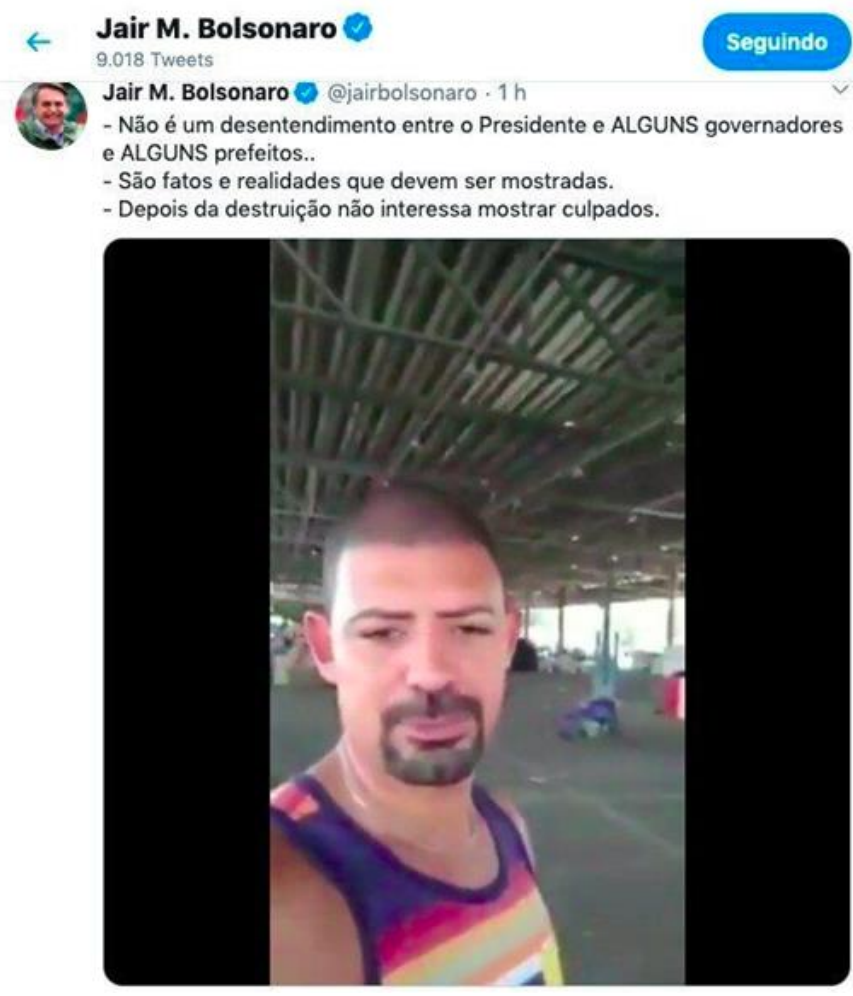

Fonte: Reprodução do Twitter de Jair Bolsonaro.

Nesse caso, o Aos Fatos identificou que não havia desabastecimento no local onde fora gravado o vídeo amador. Na verdade, o local apenas passava por uma limpeza. Bolsonaro apagou o tuíte, o que nos obrigou a recorrer a portais que noticiaram o caso à época, como o HuffPost. Destacamos que a checagem não mencionou que Bolsonaro vinha com discurso recorrentemente crítico contra as medidas de contingenciamento.

Analisando a partir dos indicativos do comportamento autoritário, visualizamos a intenção de Bolsonaro em desqualificar politicamente outras lideranças que vinham adotando medidas contrárias ao seu negacionismo. Na legenda de compartilhamento do vídeo, disse que o desabastecimento era consequência das restrições defendidas por "alguns" prefeitos e governadores. Detalhe, Bolsonaro utiliza caixa alta para escrever "alguns", o que, conforme Viscardi (2020), se encaixa como uma forma de ataque. 
Já no segundo item dessa categoria, Bolsonaro publicou os temas que abordaria em uma live no seu Facebook. No roteiro, estava a afirmação de que o STF retirara da Presidência a responsabilidade do combate ao coronavírus, colocando-a nos estados e municípios. A checagem do Aos Fatos aponta a imprecisão na afirmação de Bolsonaro, ao informar que a decisão do tribunal apenas retirava a capacidade do governo federal de derrubar medidas regionais de enfrentamento.

Figura 4. Bolsonaro divulga imagem com assuntos de live presidencial

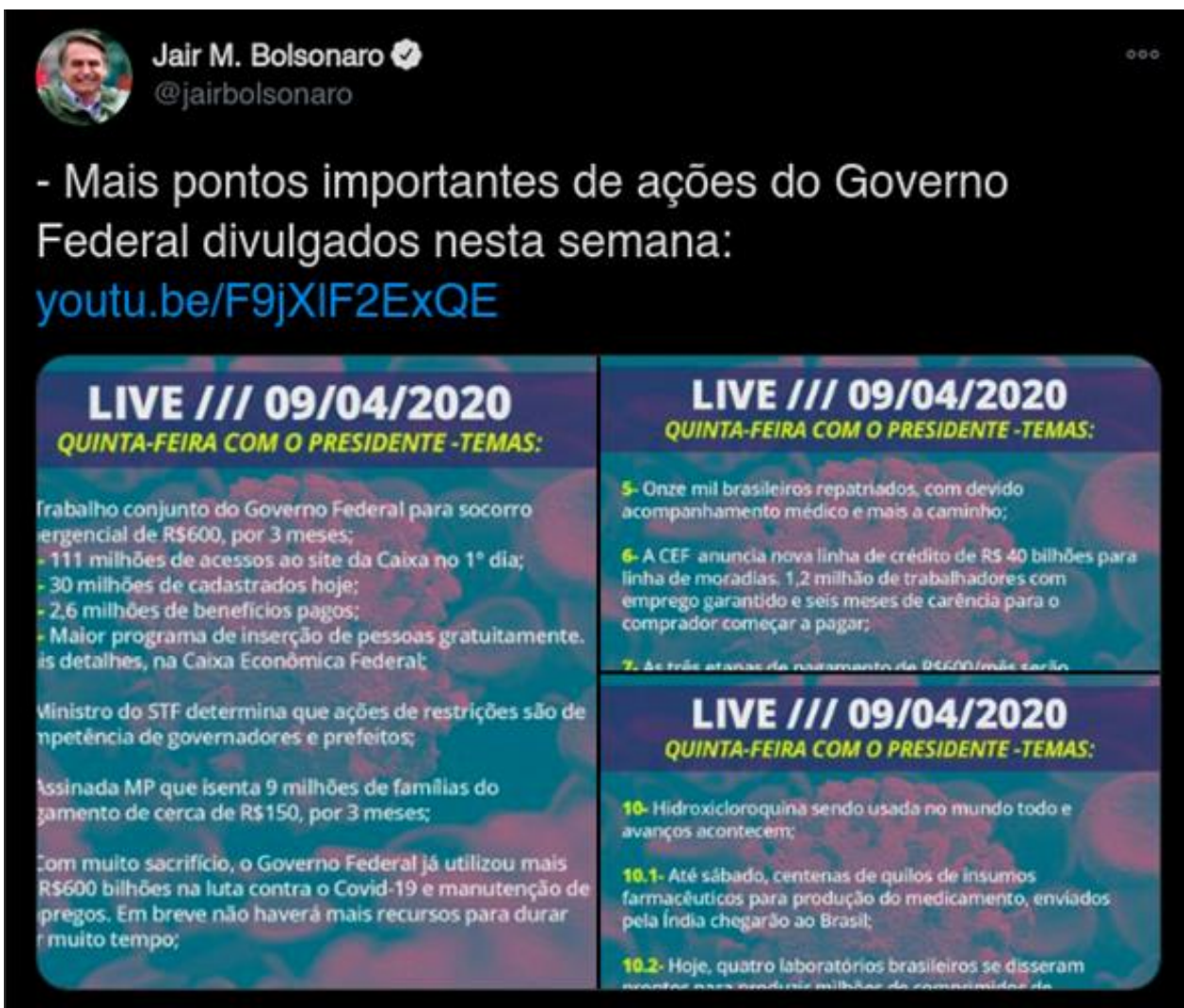

8:40 AM - 11 de abr de 2020 - Twitter for Android

4,5 mil Retweets 135 Tweets de comentário $\quad 20,4$ mil Curtidas

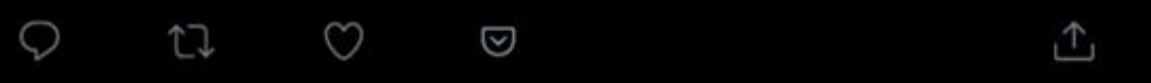

Fonte: Reprodução do Twitter de Jair Bolsonaro.

Isso significa que Bolsonaro, deliberadamente, abordou o assunto de maneira enganosa. Mais do que isso, como Bolsonaro insistiu nessa abordagem mesmo após a checagem, identificamos que uma complementação das checagens, como a inclusão de novos acontecimentos relacionados, pode ser útil para ampliar o seu alcance como ferramenta de qualificação do ambiente democrático.

No último item da categoria "Outros Poderes", Bolsonaro insistiu na já desmentida informação de que a responsabilidade era apenas de governadores e prefeitos. Ao 
mesmo tempo, menciona que iniciativas do governo federal preservaram, àquela altura, mais de 8 milhões de empregos no país.

Figura 5. Bolsonaro coloca em estados e municípios a responsabilidade de ações contra a pandemia

\section{Jair M. Bolsonaro}

@jairbolsonaro

Em resposta a @jairbolsonaro

\section{B. Apesar da responsabilidade diante do trabalhador na} pandemia ser dos estados e municípios, o@govbr desenvolve programa preservando até então mais de 8,1 milhões de empregos no país;

\section{Quarta parcela do auxílio emergencial confirmada;} @secomvc

2:29 PM · 31 de mai de 2020 - Twitter for iPhone

1,1 mil Retweets 17 Tweets de comentário $\quad 5,6$ mil Curtidas

Fonte: Reprodução do Twitter de Jair Bolsonaro.

Analisando o sentido dessa postura, vemos o objetivo de desqualificar não apenas outras esferas do poder Executivo, como também responsabilizar o Judiciário por tal fato, bem como sua própria abstenção de culpa. Claramente, Bolsonaro ataca as instituições democráticas e busca a desmoralização de outros atores políticos. Isso não apenas se encaixa como comportamento autoritário, como extrapola os itens previstos por Levitsky e Ziblatt (2018), uma vez que Bolsonaro acirra o discurso não apenas contra oponentes políticos - outrora aliados, como João Dória Jr - como antagoniza com outras esferas do poder Executivo e com o Judiciário, partes constitucionais da democracia brasileira.

Bolsonaro não pega mais leve quando está se referindo à imprensa. Em um tuíte, criticou indiretamente a Globo, cujo principal telejornal, o Jornal Nacional, apontava uma mudança de comportamento do presidente em relação ao coronavírus. Conforme a checagem do Aos Fatos, Bolsonaro mudara, sim, sua abordagem. Colecionando discursos que minimizavam as consequências da pandemia, vinha adotando um tom mais comedido em falas recentes. 
Figura 6. Bolsonaro nega mudança de tom e critica a Rede Globo.

\section{Jair M. Bolsonaro}

@jairbolsonaro

- Não há mudança de tom quando se fala em salvar vidas após alertar sobre histeria, como sugere determinada emissora. Ela sabe que ambos são problemas COEXISTENTES e que precisam ser combatidos pelo bem estar do Brasil, mas prefere tentar enganar a população.

\section{1:26 PM $\cdot 1$ de abr de 2020 - Twitter for Android}

8,9 mil Retweets $\quad 544$ Tweets de comentário $\quad 49,9$ mil Curtidas
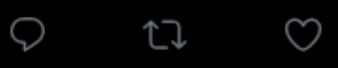

$\checkmark$

Fonte: Reprodução do Twitter de Jair Bolsonaro.

Nesse caso, recorremos à contextualização informativa para ampliar o entendimento da relação de Bolsonaro com a Rede Globo. Em algumas ocasiões, o presidente já indicava possibilidades de suspender a concessão da emissora para operar em rede aberta. Mais do que isso, seu governo vinha adotando medidas de retaliação, como redução de verbas publicitárias para a Globo, ao passo que a de canais com discurso mais governista, como SBT e Record, aumentaram.

Na última análise dentro da categoria "Imprensa", o presidente do Brasil ironiza o trabalho de jornalistas que foram cobrir sua ida até o Hospital das Forças Armadas e posterior parada em uma farmácia. Acusando os profissionais de causarem aglomeração, Bolsonaro não se preocupa em contradizer sua própria postura para criticar a imprensa. A checagem do Aos Fatos resgata o comportamento recente do presidente, causando diversas aglomerações em Brasília ou cumprimentando apoiadores sem máscara e com apertos de mão. 
Figura 7. Bolsonaro ironiza jornalistas.

Jair M. Bolsonaro

@jairbolsonaro

\section{- Retornando do Hospital das Forças Armadas parei} para comprar medicamento na Drogaria Rosário.

- Contrariando normas da Saúde os repórteres se aglomerararam.

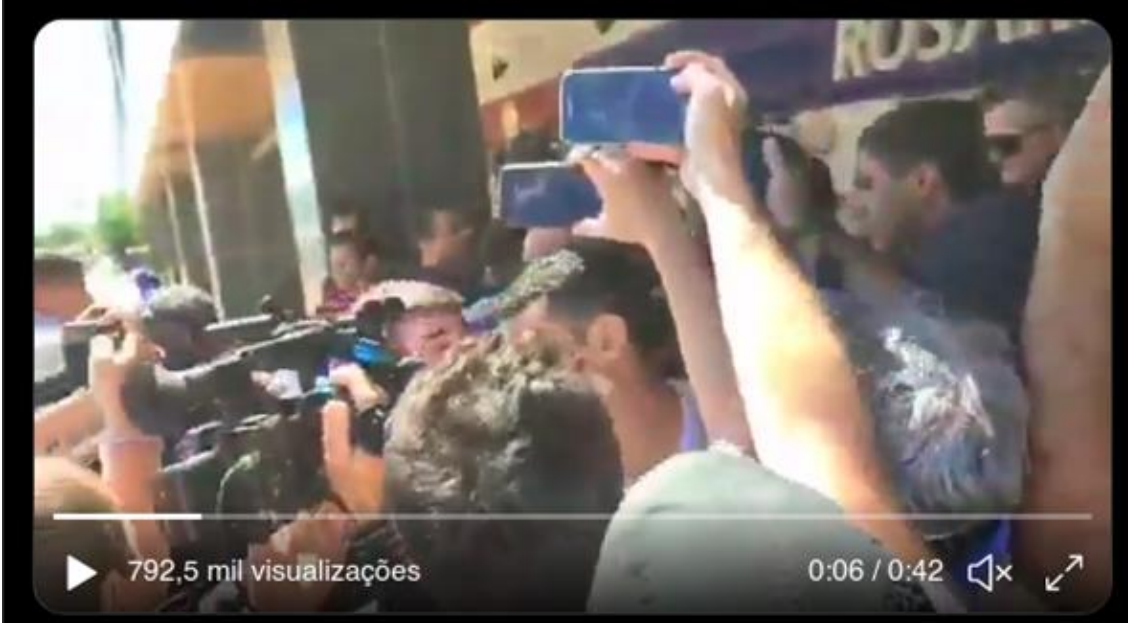

5:49 PM - 10 de abr de 2020 - Twitter for Android

12 mil Retweets $\quad 1,8$ mil Tweets de comentário $\quad 60$ mil Curtidas 
defender o uso do medicamento, Bolsonaro seguiu o raciocínio trumpista e apostou na cloroquina.

Figura 8. Bolsonaro defende a cloroquina pela primeira vez.

Jair M. Bolsonaro

@jairbolsonaro

1- Há 40 dias venho falando do uso da Hidroxicloroquina no tratamento do COVID-19. Sempre busquei tratar da vida das pessoas em $1^{\circ}$ lugar, mas também se preocupando em preservar empregos. Fiz, ao longo desse tempo, contato com dezenas médicos e chefes de estados de outros países.

8:00 AM $\cdot 8$ de abr de $2020 \cdot$ Twitter for Android

14,5 mil Retweets $\quad 1,6$ mil Tweets de comentário $\quad 71,6$ mil Curtidas

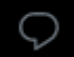

$\uparrow$

O

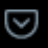

Fonte: Reprodução do Twitter de Jair Bolsonaro.

A publicação no Twitter veio no mesmo dia em que fez um pronunciamento em rede nacional, divulgando o medicamento como solução à doença. A checagem do Aos Fatos se mostra simples em desmentir o presidente. Resgatando a primeira menção de Bolsonaro ao medicamento foi apenas 20 dias antes do tuíte analisado. Ainda assim, analisamos que, dentro do contexto de incertezas e buscas por medicamentos capazes de auxiliar no tratamento da Covid-19, não é possível identificar essa como uma publicação autoritária. Testes eram realizados em diversos países para identificar a eficácia do medicamento.

No entanto, Bolsonaro já aproveitava a ocasião para politizar a cloroquina, como um investimento de capital político. Ao publicar um tuíte mencionando médicos do Estado de São Paulo que se recusavam a revelar os medicamentos que auxiliaram o processo de cura da doença, Bolsonaro insinua que o motivo para isso seria que estes usaram a cloroquina no tratamento e não abriam isso ao público por motivos políticos de proximidade com o governador paulista, João Dória Jr - antigo aliado e agora adversário político de Jair Bolsonaro. Novamente, Aos Fatos aponta que é insustentável o discurso do presidente, tendo em vista que não havia evidências aceitas de forma consensual pela comunidade científica, atestando a eficácia da cloroquina.

Três dias depois, Bolsonaro fez nova publicação, defendendo o medicamento, agora citando resultados positivos em outros países. A checagem foi novamente no mesmo 
sentido, afirmando que o medicamento não tinha qualquer eficiência comprovada, nem estava sendo usado em larga escala pelo globo.

Figura 9. Bolsonaro divulga informação falsa ao apontar avanços com o uso de cloroquina.

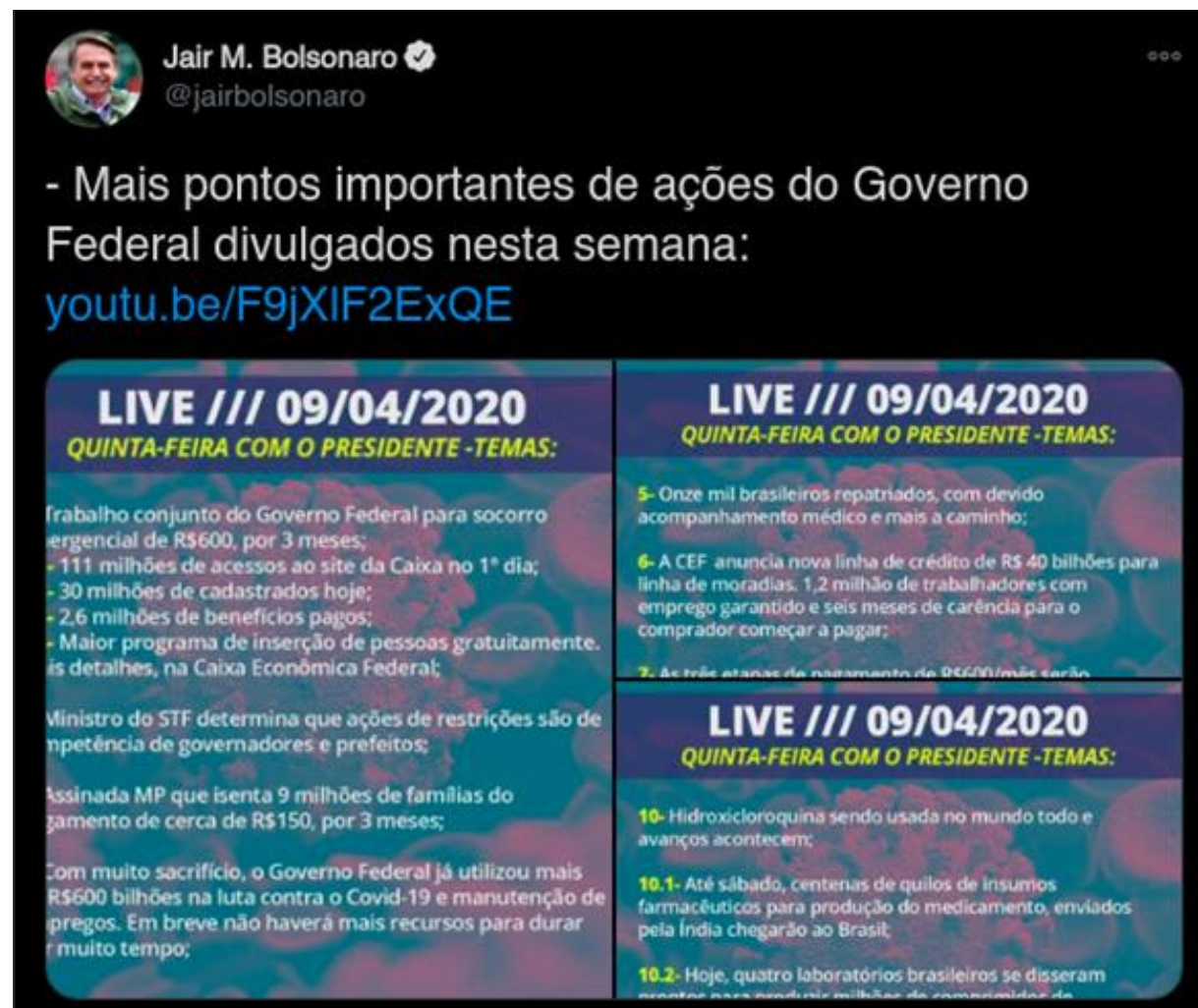

8:40 AM - 11 de abr de 2020 - Twitter for Android

4,5 mil Retweets 135 Tweets de comentário $\quad 20,4$ mil Curtidas

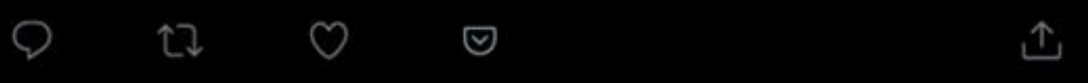

Fonte: Reprodução do Twitter de Jair Bolsonaro.

Com isso, já é possível apontar irresponsabilidade sanitária de Bolsonaro ao continuar aumentando as apostas em um fármaco sem nenhum retorno positivo observado. Consideramos isso um traço de autoritarismo, tendo em vista que o presidente privilegia a manutenção de sua narrativa em detrimento da saúde nacional e patrocinava "teorias de conspiração" contra seu governo lideradas por adversários políticos e a própria imprensa. Novamente, encontramos elementos que ultrapassam os indicativos de Levitsky e Ziblatt (2018), pois os autores não consideram a possibilidade de existência de líderes que se movimentam ativamente contra recomendações sanitárias definidas por organizações de saúde. Identificamos que a superação dos indicativos autoritários se dá pela desconsideração de Bolsonaro não apenas ao jogo político e democrático, mas também pelo negacionismo e isolamento posicional no enfrentamento de um vírus que ameaça a vida, um direito básico universal. 
Ainda assim, a defesa da cloroquina seguiu em escalada nas redes sociais presidenciais. Bolsonaro fez nova publicação, agora citando um estudo da empresa de planos de saúde Prevent Sênior. Segundo Bolsonaro, 636 pacientes foram acompanhados pelos médicos no estudo, sendo que 224 não haviam feito uso da cloroquina e cinco destes teriam falecido. Por outro lado, 412 teriam usado o medicamento e nenhum morrera. Conforme verificado pelo Aos Fatos, a afirmação é falsa. Não há menção a mortos dentre os que não usaram o medicamento, mas sim, duas mortes dentre os que usaram.

Figura 10. Bolsonaro intensifica apostas na cloroquina.

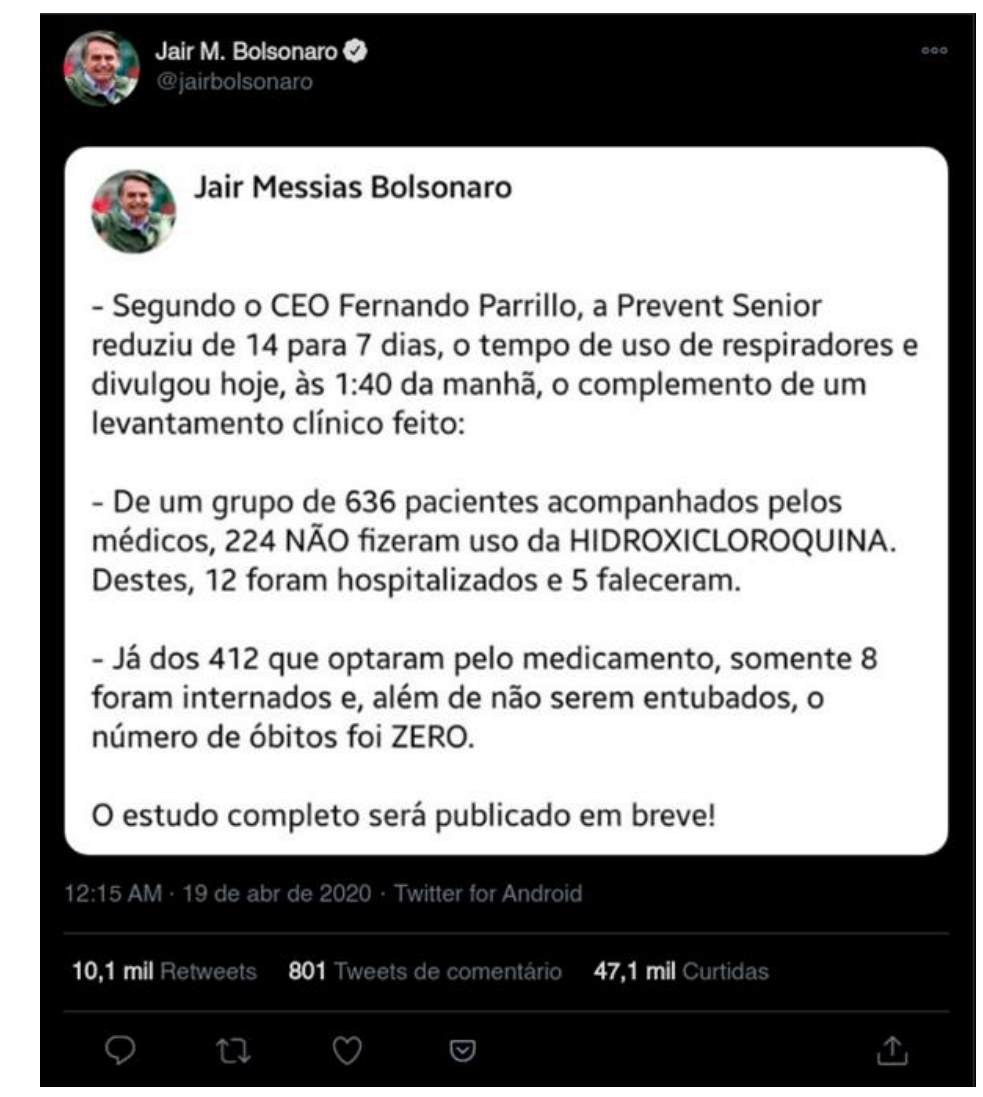

Fonte: Reprodução do Twitter de Jair Bolsonaro.

$\mathrm{Na}$ esteira da narrativa, Bolsonaro apenas compartilhou uma publicação de um portal noticioso de direita, que informava autorização do Conselho Federal de Medicina para o uso da cloroquina e hidroxicloroquina para pacientes com Covid-19. Novamente, a checagem é fundamental em reforçar a ausência de evidências da eficácia do medicamento, bem como salientar que os medicamentos, segundo o próprio CFM, não trariam benefícios a pacientes com sintomas graves ou a pacientes sem instrução médica.

O negacionismo científico em torno do assunto indica o viés autoritário do presidente ao escolher compartilhar desinformação no seu perfil no Twitter. Ao manter a defesa da hidroxicloroquina, que, além do impacto desinformativo no que se refere ao tratamento da Covid-19, acarretou outros prejuízos mais concretos a pacientes em 
tratamento de outras doenças para as quais a cloroquina é indicada, pois as declarações do presidente colaboraram para o desabastecimento do medicamento nas farmácias. Ainda, ao longo do tempo, tal indicação se revelou não apenas ineficaz, mas também perigosa, sendo notificados casos de doença do fígado tratáveis apenas com transplante e mortes decorrentes do uso indevido do "kit Covid" propagandeado pelo presidente e seus apoiadores.

\section{CONCLUSÕES}

Ao analisarmos os tuítes de Jair Bolsonaro neste estudo, algumas observações e constatações se apresentam de forma cristalina. Com a proposta de cruzarmos as publicações presidenciais verificadas pelo Aos fatos com os indicativos do comportamento autoritário definidos por Levistky e Ziblatt (2018), objetivamos identificar se Bolsonaro reproduz ou não o autoritarismo em suas falas e como elas se relacionam com padrões de veracidade - ou desinformação.

Com base no trabalho de fact-checking do site Aos Fatos, foi possível qualificar os tuítes e traçar os paralelos com o quadro dos autores estadunidenses. Quando fala sobre outros assuntos que não os classificados como Agenda/Divulgação, isto é, assuntos que não estão sob total controle, Bolsonaro falou a verdade em apenas $20 \%$ dos casos, de acordo com o Aos Fatos. Ou seja, a cada 10 posts, Bolsonaro não consegue sustentar o que diz em oito deles.

Dentro das definições de Levitsky e Ziblatt (2018), Bolsonaro ataca a imprensa, deslegitima outros poderes e desqualifica adversários políticos. No entanto, o contexto pandêmico mundial da Covid-19 trouxe um novo tipo de comportamento autoritário que não foi previsto pelos pesquisadores. Bolsonaro vai na contramão das recomendações de autoridades da saúde mundial, como a OMS, e recomenda exaustivamente medicamentos como a cloroquina, que não tem eficácia na prevenção da doença. Mais do que isso, critica, por motivações políticas, o desenvolvimento de vacinas como a CoronaVac, e contraria até mesmo recomendações mais básicas de evitar aglomerações e usar máscara. Nesse ínterim, misturam-se mecanismos autoritários e estratégias de desinformação. Combinadas, essas frentes podem causar danos não só às instituições democráticas, mas à saúde pública, dado o contexto pandêmico, e ao exercício do jornalismo, que vive sob ataque nesse cenário.

Ao chegarmos nessas constatações, concluímos que os indicativos autoritários de Levitsky e Ziblatt (2018) não são o bastante para explicar o autoritarismo "à brasileira" de Bolsonaro. Com uma das democracias mais jovens entre as maiores economias do mundo, as instituições do Brasil passam por um momento de forte instabilidade, alimentada por um político identificado com o regime militar que ditou os rumos do país entre 1964 e 1985, com apelos à censura, violência e, claro, autoritarismo.

No que se refere à contribuição do fact-checking, Traquina (2005) já afirmava a importância da informação da população como forma de qualificação da democracia, tendo em vista que cidadãos com maior conhecimento sobre os atos de seus 
representantes são mais capazes de fazer escolhas embasadas em processos eleitorais. Desse modo, a checagem de fatos como formato jornalístico se mostra como uma vertente de grande contribuição para a qualificação do processo democrático. Haja vista que atua diretamente na verificação e registro de informações de interesse público, bem como apregoa a transparência em seus métodos.

No entanto, há limitações. No contexto de fluxo contínuo e rápido de informações que circulam nas redes sociais, as publicações que etiquetam as falas de políticos como Bolsonaro são rapidamente superadas por novos posts nos feeds. O Aos Fatos disponibiliza em seu site uma forma de contornar esse imediatismo. Com um acervo com todas as declarações de Bolsonaro ${ }^{8}$, grande parte do público tem acesso fácil ao histórico de falas do presidente, o que permite a identificação do seu perfil, bem como eventuais contradições. Mas isso não é o bastante, seja pela desproporção entre a quantidade de seguidores, por exemplo, de Aos Fatos em relação a Bolsonaro nas redes, seja pela pré-disposição dos usuários a valorar mais as narrativas do que os fatos, no ambiente típico de "pós-verdade". Ou seja, aumentar o alcance é um dos desafios do fact-checking, como do jornalismo de maneira geral, mas é preciso também investir em ações de letramento midiático e leitura crítica de conteúdos digitais que estimulem a valorização de evidências.

Com a combinação de análise de conteúdo (Bardin, 1977) e análise de sentidos (Moura; Lopes, 2016), este estudo contribui para a contextualização das falas de Bolsonaro além das etiquetas de veracidade do fact-checking, expondo também a relação entre narrativas desinformativas e autoritarismo. Algo especialmente importante no contexto da desinformação, pois vai na direção das motivações que justificam a criação ou reprodução do material desinformativo - seja ele por erro de apuração, fabricação ou informação fora de contexto.

Ainda, diante do bombardeio contínuo de falas e publicações, faz-se necessário que se estude outras fontes de informação - ou desinformação - presidencial, tal como as lives ou entrevistas de Bolsonaro, onde a espontaneidade do presidente tende a ser mais evidente do que no Twitter. Acompanhar sua postura em comunicações menos controladas pode trazer resultados ainda mais contundentes quanto aos sinais de comportamento autoritário em suas declarações e como a desinformação é apropriada nesses discursos para sustentar sua narrativa autoritária.

\section{REFERÊNCIAS}

AOS FATOS, s/d. Nosso método. Aos Fatos [em linha] [Acesso em 5 de maio de 2021] Disponível em: https://www.aosfatos.org/nosso-m\%5B\%C3\%A9e\%5Dtodo/

\footnotetext{
8 Todas as declarações de Jair Bolsonaro checadas pelo site Aos Fatos. Disponível em < https://www.aosfatos.org/todas-as-declara\%C3\%A7\%C3\%B5es-de-bolsonaro/>. Acesso em $26 \mathrm{de}$ fevereiro de 2021.
} 
BARDIN, Laurence, 2000. Análise de conteúdo. Lisboa, Portugal: Edições 70.

BARBOSA, Fernando; FÁVERO, Bruno; ELY, Débora; BARBOSA, João, 2021. Bolsonaro e aliados publicaram $83 \%$ da desinformação sobre tratamento precoce no Facebook em 2021. Aos Fatos [em linha]. 24 março 2021. [Acesso em 26 março 2021] Disponível em:

https://www.aosfatos.org/noticias/bolsonaro-e-aliados-publicaram-83-dadesinformacao-sobre-tratamento-precoce-no-facebook-em-2021/

DA EMPOLI, G. 2020. Os engenheiros do caos. São Paulo: Vestígio, 192p.

DANNENBERG, Murilo, 2020. Epidemia do autoritarismo: A crise sanitária e o discurso autoritário do presidente do Brasil no Twitter. Trabalho de Conclusão de Curso (Graduação em Jornalismo). São Leopoldo, RS: Universidade do Vale do Rio dos Sinos.

GOMES, W. 2009. Jornalismo, fatos e interesses: ensaios de teoria do jornalismo. Florianópolis, Insular, 112p.

PRIOR, H. 2019. Em nome do povo: o populismo e o novo ecossistema mediático. In: Figueira J., Santos S. (ed.). As fake news e a nova ordem (des)informativa na era da pós-verdade. Coimbra, Imprensa da Universidade de Coimbra, p. 123-47.

LEVITSKY, Steven; ZIBLATT, Daniel, 2018. Como as democracias morrem. Rio de Janeiro, Brasil: Zahar.

MOURA, Cláudia; LOPES, Maria Immacolata, 2016. Pesquisa em comunicação: metodologias e práticas acadêmicas. Porto Alegre, Brasil: EDIPUCRS.

Organização Panamericana de Saúde, 2020. Entenda a infodemia e a desinformação na luta contra a Covid-19. [em linha] [Acesso em 4 janeiro 2021]. Disponível em:

https://iris.paho.org/bitstream/handle/10665.2/52054/Factsheet-

Infodemic_por.pdf?sequence $=14$

Oxford Learner's Dictionaries. Post-truth. [em linha] [Acesso em 26 março 2021] Disponível em: https://en.oxforddictionaries.com/definition/post-truth

RIBEIRO, M.M.; ORTELLADO, P. 2018. O que são e como lidar com as notícias falsas: dos sites de notícias falsas às mídias hiper-partidárias. SUR 27 - v.15 n.27 pp 71-83 [em linha] [Acesso em 27 março 2021] Disponível em: 
https://sur.conectas.org/wp-content/uploads/2018/07/sur-27-portuguesmarcio-moretto-ribeiro-pablo-ortellado.pdf

TRAQUINA, Nelson, 2005. Teorias do jornalismo. Florianópolis, Brasil: Insular.

VISCARDI, Janaisa Martins, 2020. Fake news, verdade e mentira sob a ótica de Jair Bolsonaro no Twitter. Trabalhos em Linguística Aplicada [em linha]. 2020, vol. 59, no. 2. [Acesso em 26 março 2021]. Disponível em:

https://periodicos.sbu.unicamp.br/ojs/index.php/tla/article/view/8658477

WARDLE, Claire; DERAKHASHAN, Hossein, 2017. Information disorder: Toward an interdisciplinary framework for research and policy making. Council of Europe Report [em linha]. 27 setembro 2017. [Acesso em 6 abril 2020]. Disponível em: https://edoc.coe.int/en/media/7495-information-disordertoward-an-interdisciplinary-framework-for-research-and-policy-making.html

ZARACOSTAS, J. 2020. How to fight an infodemic. The Lancet, 395(10225): 67688. 